\title{
Effect of packaging technology on microbiological and sensory quality of a cooked blood sausage, Morcela de Arroz, from Monchique region of Portugal
}

\author{
J.A. Pereira ${ }^{\text {a,b,* }}$, L. Dionísio ${ }^{\text {c,d }}$, L. Patarata ${ }^{\text {e }}$, T.J.S. Matos ${ }^{\text {b,f }}$ \\ a Department of Food Engineering, Instituto Superior de Engenharia, University of Algarve, Campus da Penha, Estrada da Penha, 8005-139 Faro, Portugal \\ b CEER - Biosystems Engineering, Tapada da Ajuda, 1349-017 Lisbon, Portugal \\ c Department of Biological Sciences and Bioengineering, Faculdade de Ciências e Tecnologia, University of Algarve, Campus de Gambelas, 8005-139 Faro, Portugal \\ d ICAAM - Institute of Mediterranean Agricultural and Environmental Sciences, P.O. Box 94, University of Évora, 702-554 Évora, Portugal \\ e CECAV - Animal and Veterinary Research Centre, University of Trás-os-Montes e Alto Douro, Quinta dos Prados, Apartado 1013, 5000-911 Vila Real, Portugal \\ ${ }^{\mathrm{f}}$ Department of Science and Biosystems Engineering, Instituto Superior de Agronomia, Technical University of Lisbon, Tapada da Ajuda, 1349-017 Lisbon, Portugal
}

\section{A R T I C L E I N F O}

Article history:

Received 9 August 2013

Received in revised form 8 September 2014

Accepted 19 September 2014

Available online 11 November 2014

\section{Keywords:}

Blood sausage

Packaging technology

Microbiology

Sensory analyses

Shelf life

\begin{abstract}
A B S T R A C T
Morcela de Arroz (MA), a popular Portuguese blood sausage, with high pH and water activity $\left(a_{\mathrm{w}}\right)$, is traditionally commercialized without preservatives and unpacked. This study evaluated the best packaging solution to extend MA shelf life stored at $4 \pm 1{ }^{\circ} \mathrm{C}$ for 44 days: without packaging (WP), vacuum (VP) and modified atmosphere packaging (MAP) $\left(80 \% \mathrm{CO}_{2} ; 20 \% \mathrm{~N}_{2}\right)$. Mesophilic (MTVC), psychrotrophic (PTVC), lactic acid bacteria (LAB), pseudomonads, molds and yeasts, Enterobacteriaceae, Listeria monocytogenes, Salmonella spp., Bacillus cereus, Clostridium perfringens, sensory properties, $\mathrm{pH}$, moisture and $a_{\mathrm{w}}$ were studied. Moisture and $a_{\mathrm{w}}$ decreased $(p<0.05)$ in WP. pH decreased in WP and MAP during storage. MTVC and PTVC counts increased to values around $7 \log \mathrm{CFU} / \mathrm{g}$ at 44 days of storage. LAB and Enterobacteriaceae counts were higher $(p<0.05)$ in VP. Pseudomonads were inhibited $(p<0.05)$ by MAP after 8 days of storage. Sensory parameters were affected $(p<0.05)$ by packaging and storage time. Globally, MAP performed better.
\end{abstract}

(c) 2014 Elsevier Ltd. All rights reserved.

\section{Introduction}

Morcela de Arroz (MA) is a popular cooked rice blood sausage, a ready to eat (RTE) meat product that is traditionally produced in Serra de Monchique (south of Portugal). This product supports the economy of several industries, due to its uniqueness among the traditional Portuguese meat products. MA is produced without addition of chemical preservatives and without the use of any packaging technology. Distribution and storage are performed in a very short period (one week at $0-5{ }^{\circ} \mathrm{C}$ ). The short shelf life has been an important hurdle to the increase of the production through the diversification of the markets, namely more distant ones.

To our knowledge, there is no information about MA, namely its microbiological, sensory or physical-chemical characteristics, that hinders any attempt to modify the commercialization conditions. Despite the information available about similar blood sausages (Cachaldora, García, Lorenzo, \& García-Fontán, 2013; Roseiro, Santos, Almeida, \&

\footnotetext{
* Corresponding author at: Department of Food Engineering, Instituto Superior de Engenharia, University of Algarve, Campus da Penha, Estrada da Penha, 8005-139 Faro, Portugal. Tel.: + 351289 800124; fax: + 351289888405 .

E-mail addresses: japer@ualg.pt (J.A. Pereira), ldionis@ualg.pt (L. Dionísio), lpatarat@utad.pt (L. Patarata), matosteresa@isa.utl.pt (T.J.S. Matos).
}

Vieira, 1998; Santos, González-Fernández, Jaime, \& Rovira, 2003), the specificity of MA makes its shelf life difficult to evaluate by comparison or extrapolation.

Blood sausages are products of difficult preservation due to the rich nutrient composition, high $\mathrm{pH}$ (about 6.0) and high $a_{\mathrm{w}}$ reaching values higher than 0.97. Although, the high temperature and cooking time (95-96 ${ }^{\circ} \mathrm{C}$ for around $1 \mathrm{~h}$ ) during processing eliminates the vegetative forms of microorganisms and only more heat resistant bacteria spores survive the treatment (Silva \& Gibbs, 2010), post-cooking contamination on the surface of the product is caused by handling of the product during cooling, refrigeration and post processing operations (Mäkelä \& Korkeala, 1987; Oteiza, Chinen, Miliwebsky, \& Rivas, 2006; Santos, Diez, González-Fernández, Jaime, \& Rovira, 2005).

The use of packaging technology can extend shelf life of meat products by improving safety and stability along shelf life. Vacuum packaging (VP), being cost-effective and easy to apply (McMillin, 2008), has been so far the most widely used packaging technique for different types of meat products (Borch, Kant-Muermans, \& Blixt, 1996). However, it presents some disadvantages, such as product deformation and exudate forming. To overcome this problem, modified atmosphere packaging (MAP) has become popular among meat products (Hintlian \& Hotchkiss, 1987; Matos, Barreto, \& Bernardo, 2005; Pexara, Metaxopoulos, \& Drosinos, 2002). $\mathrm{CO}_{2} / \mathrm{N}_{2}$ atmospheres are accepted as 
particularly adequate for the preservation of meat products, mainly because of the strong growth inhibition of the majority of microorganisms. It is accepted that $\mathrm{CO}_{2}$ increases the lag phase and generation time of microorganisms, even those that can grow in the absence of oxygen. This inhibitory effect is due to the reduction of $\mathrm{pH}$, inhibition of certain enzymes involved in energy production and damage of the cell membrane. $\mathrm{N}_{2}$ is used as a filler gas and it has no recognized inhibitory effect. The proportion of $\mathrm{CO}_{2} / \mathrm{N}_{2}$ in MAP is variable with the product and the desired shelf life (Mullan \& McDowell, 2003). Among the several studies made with blood sausages shelf life, Santos et al. (2005) concluded that the combination of $80 \% \mathrm{CO}_{2}$ and $20 \% \mathrm{~N}_{2}$ resulted in an improved control of spoilage microbiota and shelf life extension.

The aim of the present study was to evaluate the microbiological, physicochemical and sensory characteristics of Morcela de Arroz packaged in VP, MAP $\left(80 \% \mathrm{CO}_{2}\right.$ and $\left.20 \% \mathrm{~N}_{2}\right)$ and without packaging (WP) stored at $4 \pm 1{ }^{\circ} \mathrm{C}$ in order to investigate the best packaging solution to extend the shelf life period.

\section{Materials and methods}

\subsection{Formulation and processing of the $M A$}

MA was processed in a local industry according to the traditional method. Formulation included Alentejano pig breed meat (loin, shoulder, neck and bacon) (54\%); rice (13\%), pork blood (6\%), water (17\%), lard (4\%), grinded onion (3\%), salt (1\%) and spices (ground cumin, ground clove, ground pepper and mint) (2\%). Meats were minced in plates with holes of $2 \mathrm{~cm}$ diameter and mixed with raw rice, pork blood, water, grinded onion and mint, lard, salt and ground spices (Pereira, Ferreira-Dias, \& Matos, 2008). The mixture was stuffed into 60-65 mm diameter natural beef casings. MA was then transferred into a stainless steel cooking vessel and cooked in molho de moura, a broth prepared with water, whole onions, whole garlic, salt and laurel leaves at $91 \pm 5{ }^{\circ} \mathrm{C}$ for $1.5 \mathrm{~h}$. After cooking (individual weight of each MA around $250 \mathrm{~g}$ ), products were cooled at room temperature for about $2 \mathrm{~h}$ and then transferred into a refrigerated chamber $\left(4 \pm 1{ }^{\circ} \mathrm{C}\right)$ until the next day (day 0$)$. The experiment was conducted with three production batches separated in time by 2 months.

\subsection{Packaging of the $M A$}

On day 0, 45 samples for each packaging technology studied were individually packed in the producer facility: vacuum packed (VP) in a Belca V-40S packaging machine (Belca, Villabona, Spain) and MAP $\left(80 \% \mathrm{CO}_{2} / 20 \% \mathrm{~N}_{2}\right)$ in a Haratek $200 \mathrm{~A}$ packaging machine (Haratek, Astigarraga, Spain) both in oxygen and water impermeable bags Combitherm XX (dimensions of $230 \times 286 \mathrm{~mm}$ ), $115 \mu \mathrm{m}$ thickness (Wipak Walsrode $\mathrm{GmbH} \&$ Co.KG, Walsrode, Germany), with an oxygen transmission rate of $3.0 \mathrm{~cm}^{3} / \mathrm{m}^{2} \cdot 24 \mathrm{~h} \cdot \mathrm{atm}$ at $23{ }^{\circ} \mathrm{C}$ and $75 \% \mathrm{RH}$, carbon dioxide transmission rate of $13.5 \mathrm{~cm}^{3} / \mathrm{m}^{2} \cdot 24 \mathrm{~h} \cdot \mathrm{atm}$ at $23{ }^{\circ} \mathrm{C}$ and $75 \% \mathrm{RH}$ and a water vapor transmission rate of $1.0 \mathrm{~g} / \mathrm{m}^{2} .24 \mathrm{~h}$ at $23{ }^{\circ} \mathrm{C}$ and $85 \% \mathrm{RH}$. Samples to be studied without package (WP) were transported to the laboratory in sterile sample bags. All samples were transported under refrigeration to the laboratory and stored at $4 \pm 1{ }^{\circ} \mathrm{C}$ and $80 \%$ of $\mathrm{RH}$ (Fitoclima s $600 \mathrm{PLH}$, Aralab, Lisbon, Portugal). Selection of $80 \%$ of $\mathrm{RH}$ was based on the results of $\mathrm{RH}$ measurement in two industries and two retailer's refrigerators. WP samples were taken out from the sterile bags and stored without any package, to simulate the usual practice of commercialization of MA. Nine extra sausages were collected from each batch and transported in the same conditions (under refrigeration in sterile sample bags) to the analysis of the first sampling time, and analyzed immediately on arrival to the laboratory.

\subsection{Sampling procedure}

One experimental unit, thereafter designated as repetition, was composed by two MA, one to perform microbiological and physicochemical analysis and the other for sensory analysis, once only one MA was not enough for all analysis due to the high consumption of sample by the eighteen member of sensory analysis panel.

The experiment was conducted with 9 repetitions for each experimental condition (packaging $\times$ storage time). These 9 repetitions were obtained from 3 producing batches, separated in time by 2 months, collecting 3 samples from each of the 3 batches. Thus, for each storage time, 27 samples were analyzed [ 3 packaging (WP/VP/ $\mathrm{MAP}) \times 3$ production batches $\times 3$ repetitions from each batch]. In the first storage time (day 0 ) only 9 samples were analyzed, once there was no packaging yet ( 3 production batches $\times 3$ repetitions in each batch). During storage period samples were collected at days 8, 15, 22, 30 and 44 for microbiological, physicochemical and sensory analysis. At first sampling time (day 0) samples not packaged were analyzed immediately after arrival to the laboratory. Extra MA samples packed in each condition were maintained for all the experimental conditions to be used in case of package damage and vacuum or MAP loss. Samples used for sensory analysis panel selection,training and lexicon development are indicated in Sections 2.6.1.1 and 2.6.1.2.

\subsection{Physical-chemical analysis}

\subsubsection{Analysis of gas composition}

Oxygen and carbon dioxide concentrations in the head space of the MAP packages were measured with a digital $\mathrm{O}_{2}$ and $\mathrm{CO}_{2}$ analyzer (OXYBABY V O $\mathrm{O}_{2} / \mathrm{CO}_{2}$ WITT-Gasetechnik, Witten, Germany). $6 \mathrm{ml}$ gas samples were drawn by the needle of the analyzer through a rubber seal glued on the surface of the pack. Detection limits for $\mathrm{O}_{2}$ and $\mathrm{CO}_{2}$ were $\pm 0.1 \%$ and $\pm 2 \%$, respectively.

\subsection{2. $\mathrm{pH}$, moisture and $a_{w}$ parameters}

The potentiometric measurements of $\mathrm{pH}$ were carried out by inserting the pin electrode of the pH meter (GLP 21, Crison, Barcelona, Spain) directly into the sample $\left(20.5 \pm 0.3^{\circ} \mathrm{C}\right)$. Prior to the moisture and $a_{\mathrm{w}}$ measurements, each sample was ground and homogenized in a domestic food processor. Moisture was determined using a Mettler LP16-M infrared scale (Mettler Instruments AG, Zurich, Switzerland). Rotronic Hygroskop DT was employed to measure the water activity at $25.0 \pm 0.01{ }^{\circ} \mathrm{C}$ (Rotronic, HygroLab, Bassersdorf, Switzerland). Determinations were made in triplicate.

\subsection{Microbiological analysis}

Twenty-five-gram slices of MA were taken aseptically and homogenized with $225 \mathrm{ml}$ of sterile Ringer's solution (Merck, Darmstadt, Germany) for $90 \mathrm{~s}$ in sterile plastic bag in a lab blender (Masticator, IUL Instruments, Barcelona, Spain). Serial decimal dilutions in sterile Ringer's solution were prepared and $1 \mathrm{ml}$ or $0.1 \mathrm{ml}$ samples of appropriate dilutions were poured or spread onto nutrient agar and selective agar plates. Mesophilic total viable count (MTVC) was determined on Plate Count Agar (PCA, Merck), incubated at $30{ }^{\circ} \mathrm{C}$ for $72 \mathrm{~h}$; psychrotrophics (PTVC) were determined on PCA, incubated at $6.5^{\circ} \mathrm{C}$ for 10 days; lactic acid bacteria (LAB) on Man Rogosa and Sharpe (Merck) and incubated on anaerobic conditions at $30{ }^{\circ} \mathrm{C}$ for $2-3$ days; Enterobacteriaceae on Violet Red Bile Glucose Agar (Merck), incubated at $37{ }^{\circ} \mathrm{C}$ for $24 \mathrm{~h}$; Pseudomonas spp. on Pseudomonads Agar Base (Oxoid, Basingstoke, UK) with Cetrimide, Fucidin and Cephalosporin supplement, incubated at $25{ }^{\circ} \mathrm{C}$ for $48 \mathrm{~h}$, molds and yeasts on Chloramphenicol Rose Bengal (Merck) and incubated at $25^{\circ} \mathrm{C}$ for 5 days; detection of Salmonella spp. was performed according to EN 12824 (1997) and detection of Listeria monocytogenes according to ISO 11290-1 






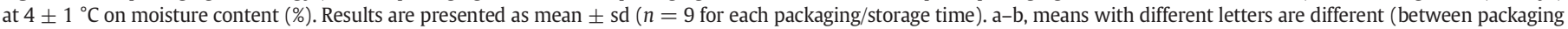
technologies at each day of storage) $(p<0.05)$. A-F, means with different letters are different (same packaging technology along time of storage) $(p<0.05)$.

(1996); Bacillus cereus according to ISO 7932 (2004) and Clostridium perfringens as described in ISO 7937 (2004).

The results are presented as log CFU/g. For statistical purposes, when the microorganism count was below the detection limit, it was considered to be zero and when countable colonies were present, but below the countable range, the estimated count was considered for data analysis.

\subsection{Sensory analysis}

\subsubsection{Quantitative descriptive analysis (QDA)}

2.6.1.1. Formation of the panel. A panel of 18 assessors was selected from an initial group of 63 recruited individuals (internal recruitment) and subsequently trained how to carry out the necessary analysis. Selection of a shortlist of 38 individuals was based on their capacity to detect and identify different tastes and aromas, ability to memorize sensory attributes, discriminative capacity and accuracy of their vocabulary in describing sensory parameters. Selection of the final 18 assessors was based on their discriminative capacity and repeatability calculated using the data obtained in repeated quantitative descriptive analyses of nine samples of MA in three sessions held at 1-week intervals (ISO 8586-1, 1993). Before performing the evaluation of the samples of the present work, the panel was trained during 10 sessions of $45-60 \mathrm{~min}$. The panelists performed sensory analysis on a total of 27 samples of MA from 12 different origins ( 2 or 3 samples in each session).
2.6.1.2. Generation of vocabulary. Descriptors for the QDA were generated in five stages according to ISO 11035 (1994): 1 - sessions of free and open generation of vocabulary, where assessors used the descriptors they considered more correct for describing the fresh and aged MA with different storage times, correspondent to different levels of spoilage; 2 - synthesis of vocabulary, determination of frequency of use and elimination of incorrectly used descriptors; 3 - test of an initial list of nineteen descriptors; 4 - data analysis to detect redundant descriptors and selection of the most discriminative descriptors between fresh and not fresh product; 5 - test of the final list. These stages were organized over nine sessions.

For the final list of 16 descriptors, definitions and references were established, proposed by the panel leader, and discussed with the panelists. It was used as references the freshly cooked MA and unpackaged refrigerated MA stored for 7 to 44 days to achieve the desired sensory parameter intensity. The choice of using the product under study rather than other matrixes as a reference was considered to be more useful to generalize sensory concepts, as suggested by Braghieri et al. (2012).

The descriptors retained in the final list to evaluate shelf life of the MA were as follows: Aspect - moisture: moistness surface property relating to the perception of the amount of water; slime: presence of viscous substance in the surface; typical color: characteristic dark brown color; brightness: light reflection due to melting of fat, greasy surface; Aroma - typical odor: characteristic meaty and spicy odor; off-odors: any atypical odor considered not expected in the product; rancid: associated with oxidized fat and oils, putrid: the pungent ammonic like odor in advanced spoiled meat or fish; sour/fermented:

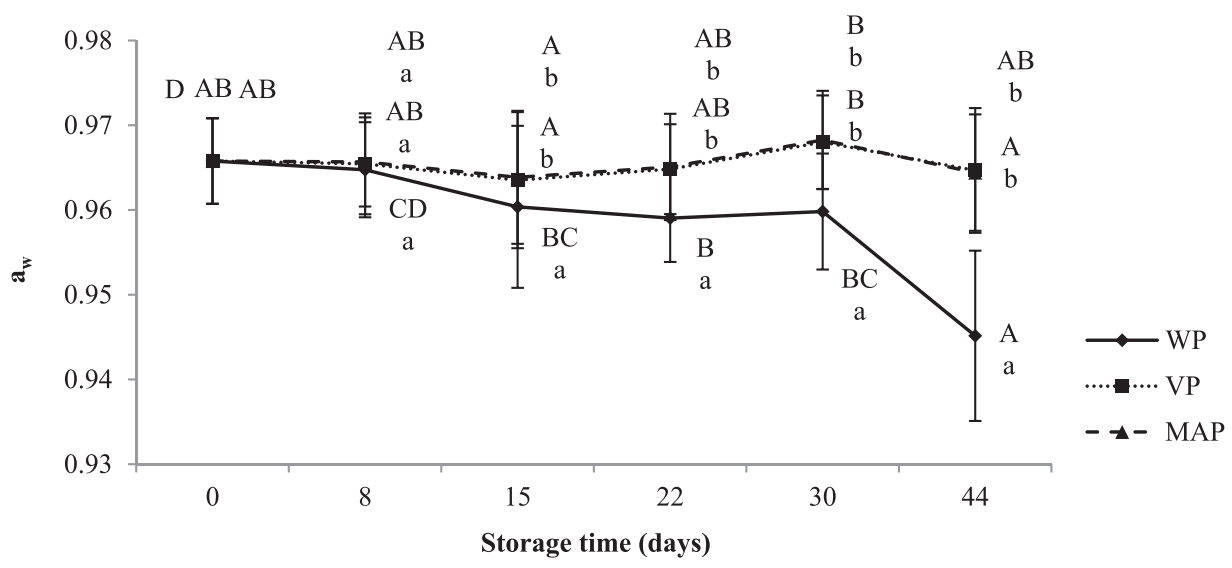

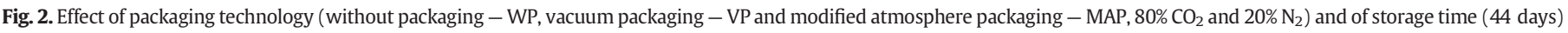

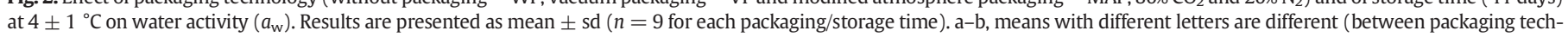
nologies at each day of storage) $(p<0.05)$. A-D, means with different letters are different (same packaging technology along time of storage) ( $p<0.05)$. 




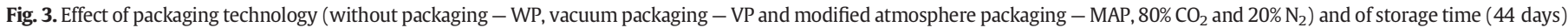

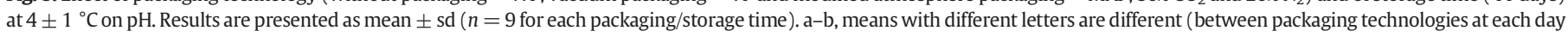
of storage) $(p<0.05)$. A-C, means with different letters are different (same packaging technology along time of storage) $(p<0.05)$.

pungent odor associated to spoiled cooked rice; spoiled wine/vinegary: acetic odor associated to vinegar; moldy/mildew: characteristic odor of molds; Flavor - typical flavor: characteristic meaty, salted and slightly sweet flavor; acid: taste like vinegar or lemon juice; bitter: acrid and harsh taste, as the peel of an orange or coffee dregs; global evaluation of freshness: multifactorial evaluation of freshness, by opposition to spoilage. Additionally, a freshness global evaluation of the entire packed product (external appearance) was introduced. The assessors were asked to score each descriptor in each sample on a scale from 1 (low intensity) to 5 (intense).

\subsubsection{Evaluation of the samples}

Sessions took place on a sensory analysis laboratory equipped with individual assessment booths and uniform lightening and temperature conditions. To guarantee test repeatability, the samples were cut in $1 \mathrm{~cm}$ thick slices and placed in Petri dishes codified with a randomized three digit number and evaluated at room temperature. Spring water and unsalted crackers were provided to clean the mouth between samplings.

\subsection{Statistical analysis}

The experiment was composed by a total of 144 observations used for statistical analysis [ 9 samples for day 0 ( 3 batches $\times 3$ repetitions $)+135$ samples ( 5 storage times $\times 3$ packaging $\times 3$ production batches $\times 3$ repetitions from each batch)].
The analysis of variance was performed with the packaging or storage time as individual effects on the microbiological and sensory variables by one-way ANOVA procedures. When the effect of storage time was analyzed by ANOVA, data from sampling time 0 (day 0 ) was used for the three packaging conditions. The differences between the mean values were determined using the Tukey test. The relationship between variables was established through Pearson correlation.

The chi-squared test was applied to evaluate the relationship between the presence/absence of B. cereus in MA and (1) the packaging technology in each sampling time and (2) the storage period in each package. Statistical significance was set at $p$ values less than 0.05 . Data analysis was performed using the IBM SPSS Statistics for Windows, Version 19.0 (IBM Corp., 2010).

\section{Results}

\subsection{Physical-chemical analysis}

The $\mathrm{CO}_{2}$ concentration of the MAP samples decreased by $19 \%$ during the storage period. The initial moisture content was $52.49 \pm 2.08 \%$ (Fig. 1) and significantly $(p<0.05)$ decreased in the WP samples during storage time (20\% loss). The initial $a_{\mathrm{w}}$ was $0.966 \pm 0.005$ (Fig. 2) and followed a similar trend to that observed for moisture (decreased nearly 0.02 units until 44 days). At day 0 , the $\mathrm{pH}$ of MA was $6.36 \pm 0.06$ (Fig. 3). During most part of the storage time, the MAP MA presented a significantly $(p<0.05)$ lower $\mathrm{pH}$ comparatively to WP and VP samples, reaching the lowest values at day 22 of the study $(\mathrm{pH}=6.19 \pm 0.06)$.

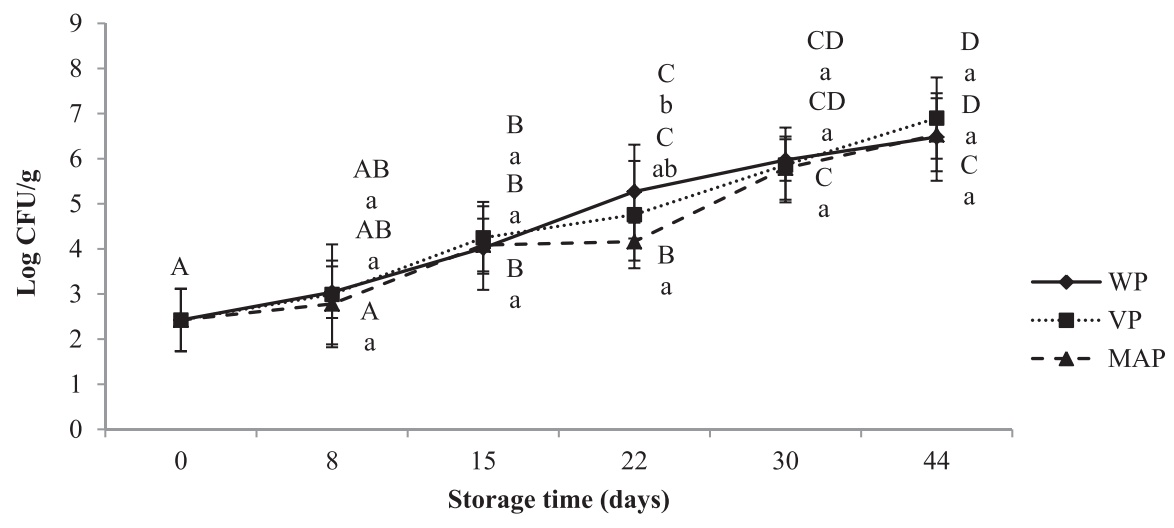

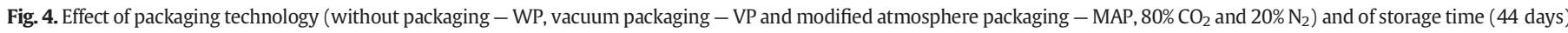

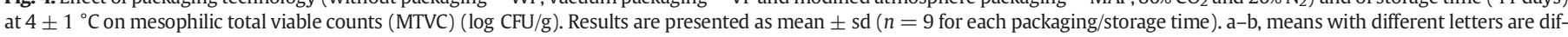

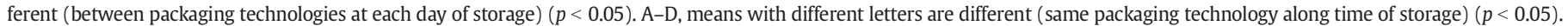




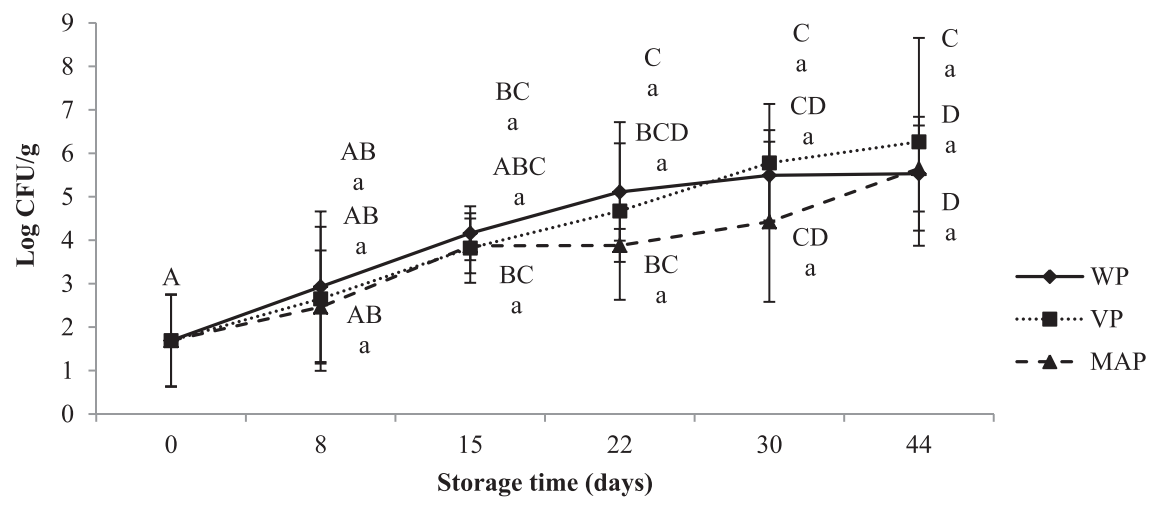

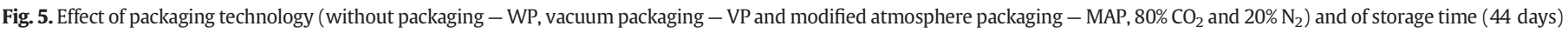

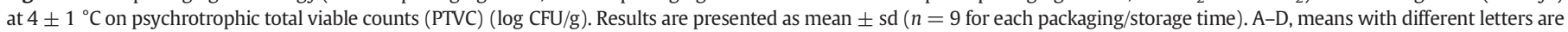
different (same packaging technology along time of storage) $(p<0.05)$.

\subsection{Microbiological analysis}

C. perfringens, L. monocytogenes and Salmonella spp. we're not detected in any of the samples tested during all the experiment in any of the package technologies used. B. cereus (results not shown) was not detected in MA freshly prepared (day 0 ). At 8 days of storage and thereafter it was punctually detected in the three packaging conditions, in a total of 18 samples, without any significant $(p>0.05)$ association either to packaging or storage time, except at 22 days of storage when all the samples with $B$. cereus were stored WP $\left(\chi^{2}=9.39, p=0.09\right)$.

The results of the counts of total viable count at $30{ }^{\circ} \mathrm{C}$ (MTVC) and at $6.5{ }^{\circ} \mathrm{C}$ (PTVC), LAB, Enterobacteriaceae and Pseudomonas spp. are presented in Figs. 4, 5, 6, 7 and 8, respectively. During the storage of MA the MTVC and PTVC increased concomitantly from a count of $2.42 \pm$ $0.69 \log \mathrm{CFU} / \mathrm{g}$ and $1.69 \pm 1.06 \log \mathrm{CFU} / \mathrm{g}$, respectively, to values around $7 \mathrm{log}$ CFU/g at the end of the storage period (44 days). The increase in the TVC counts was about $1 \log$ CFU/g in each storage interval studied. Generally both TVCs were not affected by the packaging methodology. Only at 22 days of storage a higher $(p<0.05)$ count of mesophilic was observed in samples stored without package than those packaged in MAP. For the entire storage time of the study the counts of LAB (Fig. 6) were always higher $(p<0.05)$ in the VP samples than in WP and MAP, except in the day 15 of storage. The counts of LAB increased faster in the VP MA, as inferred by the significant differences $(p<0.05)$ between the counts at the beginning of the experiment and after 8 days of storage. The higher increase of LAB occurred between 8 and 15 days of storage, nearly $1.5 \log \mathrm{CFU} / \mathrm{g}$.

The count of Enterobacteriaceae (Fig. 7) was generally lower in MAP samples. At the beginning of the experiment, any Enterobacteriaceae colony was detected. During storage it presented an increase, that was always lower in samples packaged in MAP, with significant differences $(p<0.05)$ at $8,22,30$ and 44 days of storage comparatively to VP samples and at days 8, 22 and 30 comparatively to the WP samples. Pseudomonas spp. (Fig. 8) were not detected at day 0 of the study, although, in the WP samples their counts significantly increased $(p<0.05)$ along the storage period, achieving about $1.5 \log \mathrm{CFU} / \mathrm{g}$ on day 8 of the study and reaching a plateau of $4.5 \log \mathrm{CFU} / \mathrm{g}$ at 22 days of storage, after which their counts remained similar until the end of the storage period but were always significantly higher $(p<0.05)$ comparatively to the packaged MA. In the packaged MA, Pseudomonas spp. showed a growth rate that was similar both on VP and MAP only until 8 days of storage $(p>0.05)$. After 8 days of storage on, the MAP MA presented significantly lower $(p<0.05)$ counts of Pseudomonas spp. comparatively to the VP MA. The growth of Pseudomonads in MAP was not significantly $(p>0.05)$ affected by the storage time. The count of molds and yeasts was below the detection limit in all samples until 15 days of storage. At day 22 and thereafter these microorganisms were punctually detected, 2 samples in day 22, 4 in day 30 and 2 in day 44. No association was established between the occurrence of molds and yeasts and the package technology used.

\subsection{Sensory analysis}

The results of the sensory analysis of WP, VP and MAP MA during 44 days on refrigerated storage $\left(4 \pm 1{ }^{\circ} \mathrm{C}\right)$ are presented in Table 1 . Sensory parameters were significantly $(p<0.05)$ affected by the method of packaging and storage time. In general, the sensory quality decreased during storage time. MA stored in MAP presented higher mean scores

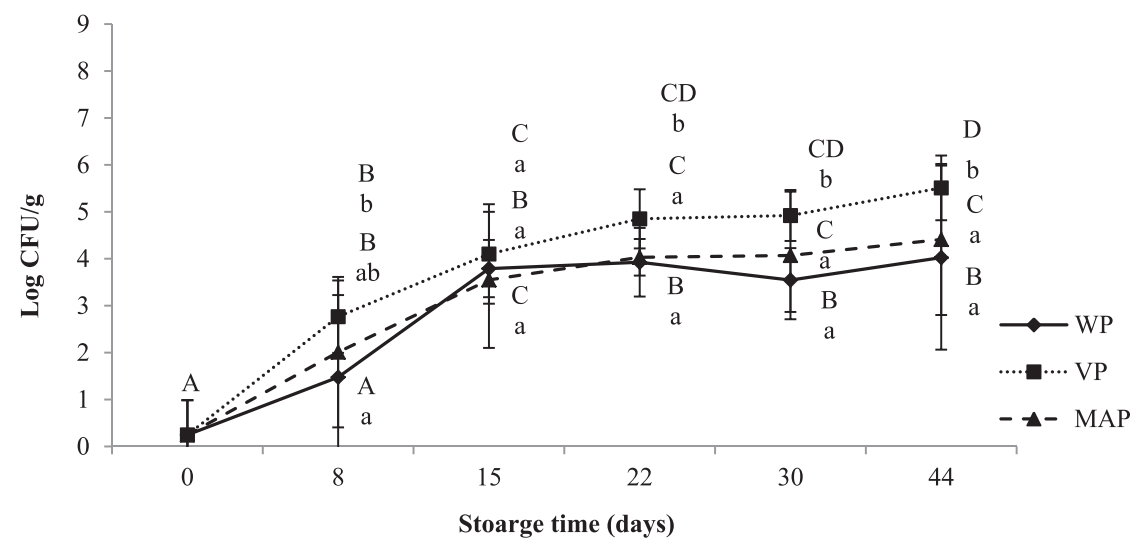



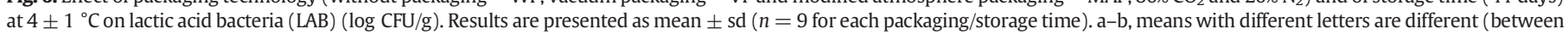
packaging technologies at each day of storage) $(p<0.05)$. A-D, means with different letters are different ( same packaging technology along time of storage) $(p<0.05)$. 


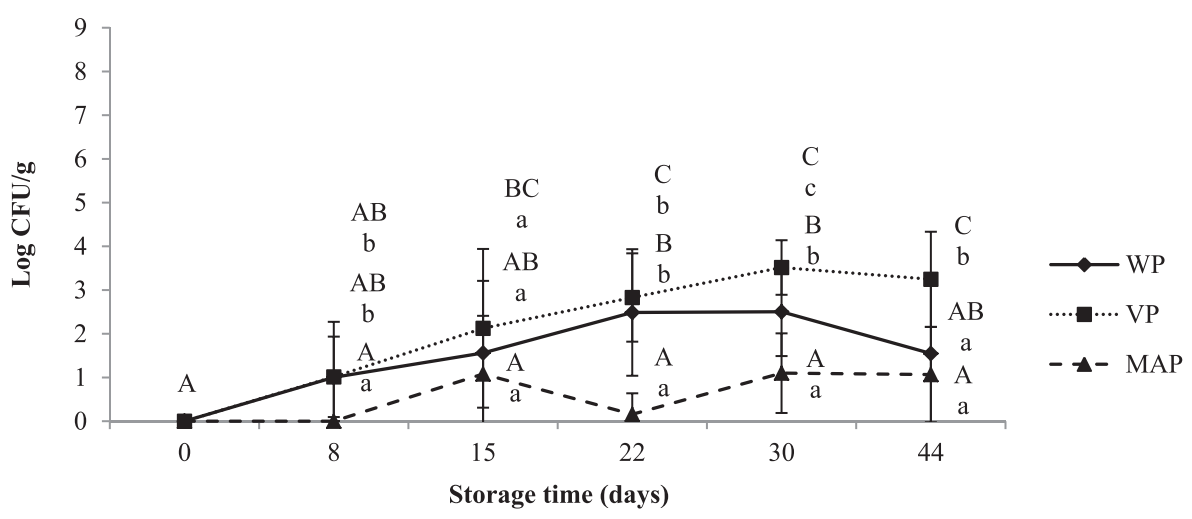

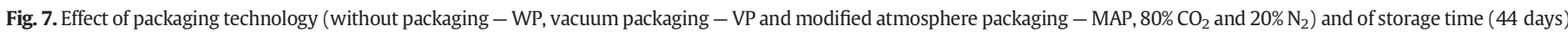

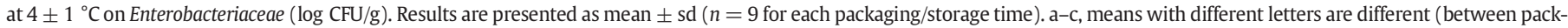
aging technologies at each day of storage $)(p<0.05)$. A-C, means with different letters are different (same packaging technology along time of storage) $(p<0.05)$.

than VP and this higher than WP samples. In the freshly prepared MA, no off-odors, rancid, putrid, sour/fermented, spoiled wine/vinegary, moldy/mildew and putrid odors were detected. The WP presented lower $(p<0.05)$ moisture aspect, typical color and typical odor and flavor at 8 days of storage and thereafter than VP and MAP MA. Presence of off-odors and rancid odor began to be significantly higher $(p<0.05)$ in the WP samples after 8 days of storage. In the WP samples the rancid odor at 44 days of storage was threefold higher than in freshly prepared MA. At 8 days of storage, WP samples began to be considered less $(p<0.05)$ fresh than those packaged, regardless the evaluation made in slices or in packaged MA. The development of the depreciative characteristics: slime, sour/fermented, spoiled wine/vinegary and moldy/ mildew odor and acid and bitter tastes were slower than the rancid and off-odors, as they became significantly different in WP samples only after 22 days of storage. From the sensory point of view, VP and MAP had a similar performance for the most of the tested attributes. However, MAP samples were generally more bright $(p<0.05$ after day 8 ), and, for longer storage periods (22 days and after), it presented a higher $(p<0.05)$ typical flavor and global freshness (slices or packaged). The evaluation of global freshness in slices or in entire packaged MAP MA during all the experiment reveals that these characteristics were stable during the tested period. The relationship between microbial counts and sensory characteristics was established by Pearson correlations for each packaging technology. Considering only the global freshness (Table 2), it was observed high significant correlations between total viable counts (MTVC and PTVC) and the sensory evaluation of freshness. These correlations were higher in WP samples. When the correlations were established between the specific spoilage microorganisms and the global freshness, it was possible to observe that LAB were particularly important in the deterioration of VP and MAP, Enterobacteriaceae in VP, and Pseudomonas spp. in WP samples, as can be observed by the higher correlation coefficient.

\section{Discussion}

The results for the mean initial $\mathrm{pH}, a_{\mathrm{w}}$ and moisture content were similar to those found by Santos et al. (2003) in a Spanish blood sausage which confirm that MA is a RTE meat product of difficult preservation. The significant decrease in $\mathrm{pH}$ values in the MAP samples comparatively to the VP and WP was probably due to the solubilization of $\mathrm{CO}_{2}$ in the product, once the conditions were favorable for that, namely the high $\mathrm{CO}_{2}$ content of the packages and the low temperature used in the experiment (Mullan \& McDowell, 2003). Additionally, no correlation was observed between $\mathrm{pH}$ evolution and LAB or other microbial group counts for any of the packaged methods, indicating that the $\mathrm{pH}$ evolution was independent of the microbial growth.

The traditional method of distribution and commercialization of MA without package (WP) was responsible for a considerable moisture loss. The drying effect during cold storage has several consequences, beyond the direct economic ones due to weight loss. The reduction of $a_{\mathrm{w}}$ resulting from the drying of MA was small, when related to the total moisture loss (around 20\%). That unexpected relationship might be a consequence of the composition of MA, namely the high level of rice and blood. The binding of water to these components of MA is expected to be weaker than the binding in sausages made only with meat and fat, once carbohydrates have a lower water binding capacity than muscular proteins (Le Maguer, 1987), and the effect of blood on the water holding capacity is variable (Jarmoluk \& Pietrasik, 2003). Despite the general



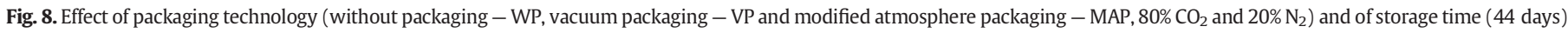

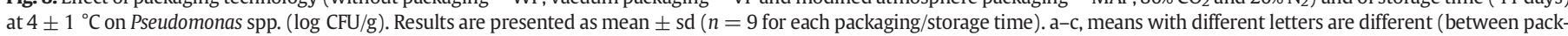
aging technologies at each day of storage) $(p<0.05)$. A-C, means with different letters are different (same packaging technology along time of storage) $(p<0.05)$. 
Table 1

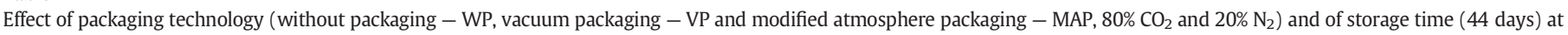
$4 \pm 1{ }^{\circ} \mathrm{C}$ on sensory parameters of Morcela de Arroz (MA). Results are presented as mean \pm standard deviation ( $n=9$ for each packaging/storage time).

\begin{tabular}{|c|c|c|c|c|c|c|c|}
\hline \multirow[t]{2}{*}{ Sensory parameter } & \multirow[t]{2}{*}{ Pack } & \multicolumn{6}{|c|}{ Storage time at $4 \pm 1{ }^{\circ} \mathrm{C}$ (days) } \\
\hline & & 0 & 8 & 15 & 22 & 30 & 44 \\
\hline \multirow[t]{3}{*}{ Moisture } & WP & $3.98 \pm 0.80^{1 ; D}$ & $2.91 \pm 0.88^{\mathrm{a} ; \mathrm{B}, \mathrm{C}}$ & $3.11 \pm 1.09^{\mathrm{a} ; \mathrm{C}}$ & $2.48 \pm 1.22^{\mathrm{a} ; \mathrm{A}, \mathrm{B}}$ & $2.60 \pm 1.39^{\mathrm{a} ; \mathrm{A}, \mathrm{B}, \mathrm{C}}$ & $2.18 \pm 1.38^{\mathrm{a} ; \mathrm{A}}$ \\
\hline & $\mathrm{VP}$ & $3.98 \pm 0.80^{C}$ & $3.51 \pm 1.01^{\mathrm{b} ; \mathrm{B}}$ & $3.58 \pm 0.93^{\mathrm{b} ; \mathrm{B}, \mathrm{C}}$ & $3.15 \pm 0.87^{\mathrm{b} ; \mathrm{A}, \mathrm{B}}$ & $3.25 \pm 0.83^{\mathrm{b} ; \mathrm{A}, \mathrm{B}}$ & $2.96 \pm 0.89^{\mathrm{b} ; \mathrm{A}}$ \\
\hline & MAP & $3.98 \pm 0.80^{\mathrm{B}}$ & $3.49 \pm 0.99^{\mathrm{b} ; \mathrm{A}}$ & $3.58 \pm 0.91^{\mathrm{b} ; \mathrm{A}, \mathrm{B}}$ & $3.21 \pm 0.94^{\mathrm{b} ; \mathrm{A}}$ & $3.43 \pm 0.77^{\mathrm{b} ; \mathrm{A}}$ & $3.24 \pm 0.79^{\mathrm{b} ; \mathrm{A}}$ \\
\hline \multirow[t]{3}{*}{ Slime } & WP & $1.04 \pm 0.20^{\mathrm{A}}$ & $1.13 \pm 0.44^{\mathrm{a} ; \mathrm{A}}$ & $1.21 \pm 0.49^{\mathrm{a} ; \mathrm{A}}$ & $1.67 \pm 0.91^{\mathrm{b} ; \mathrm{B}}$ & $1.74 \pm 1.11^{\mathrm{b} ; \mathrm{B}}$ & $1.96 \pm 1.23^{\mathrm{b} ; \mathrm{B}}$ \\
\hline & VP & $1.04 \pm 0.20^{\mathrm{A}}$ & $1.30 \pm 0.67^{\mathrm{a} ; \mathrm{A}, \mathrm{B}}$ & $1.36 \pm 0.81^{\mathrm{a} ; \mathrm{B}}$ & $1.19 \pm 0.39^{\mathrm{a} ; \mathrm{A}, \mathrm{B}}$ & $1.21 \pm 0.49^{\mathrm{a} ; \mathrm{A}, \mathrm{B}}$ & $1.18 \pm 0.39^{\mathrm{a} ; \mathrm{A}, \mathrm{B}}$ \\
\hline & MAP & $1.04 \pm 0.20^{\mathrm{A}}$ & $1.23 \pm 0.51^{\mathrm{a} ; \mathrm{B}}$ & $1.13 \pm 0.34^{\mathrm{a} ; \mathrm{A}, \mathrm{B}}$ & $1.10 \pm 0.31^{\mathrm{a} ; \mathrm{A}, \mathrm{B}}$ & $1.08 \pm 0.27^{\mathrm{a} ; \mathrm{A}, \mathrm{B}}$ & $1.20 \pm 0.45^{\mathrm{a} ; \mathrm{A}, \mathrm{B}}$ \\
\hline \multirow[t]{3}{*}{ Typical color } & WP & $4.58 \pm 0.67^{\mathrm{D}}$ & $3.55 \pm 1.05^{\mathrm{a} ; \mathrm{c}}$ & $3.19 \pm 0.96^{\mathrm{a} ; \mathrm{c}}$ & $1.98 \pm 1.02^{\mathrm{a} ; \mathrm{B}}$ & $1.87 \pm 0.98^{\mathrm{a} ; \mathrm{B}}$ & $1.33 \pm 0.68^{\mathrm{a} ; \mathrm{A}}$ \\
\hline & $\mathrm{VP}$ & $4.58 \pm 0.67^{\mathrm{B}}$ & $4.02 \pm 0.97^{\mathrm{b} ; \mathrm{A}}$ & $3.83 \pm 0.99^{\mathrm{b} ; \mathrm{A}}$ & $3.75 \pm 0.76^{\mathrm{b} ; \mathrm{A}}$ & $3.60 \pm 1.03^{\mathrm{b} ; \mathrm{A}}$ & $3.59 \pm 0.92^{\mathrm{b} ; \mathrm{A}}$ \\
\hline & MAP & $4.58 \pm 0.67^{\mathrm{B}}$ & $4.06 \pm 1.01^{\mathrm{b} ; \mathrm{A}}$ & $4.00 \pm 0.90^{\mathrm{b} ; \mathrm{A}}$ & $3.71 \pm 0.97^{\mathrm{b} ; \mathrm{A}}$ & $3.89 \pm 0.85^{\mathrm{b} ; \mathrm{A}}$ & $3.78 \pm 0.97^{\mathrm{b} ; \mathrm{A}}$ \\
\hline \multirow[t]{3}{*}{ Brightness } & WP & $3.86 \pm 0.81^{\mathrm{B}}$ & $2.96 \pm 1.06^{\mathrm{a} ; \mathrm{A}}$ & $3.04 \pm 0.94^{\mathrm{a} ; \mathrm{A}}$ & $2.58 \pm 1.32^{\mathrm{a} ; \mathrm{A}}$ & $2.72 \pm 1.34^{\mathrm{a} ; \mathrm{A}}$ & $2.53 \pm 1.58^{\mathrm{a} ; \mathrm{A}}$ \\
\hline & $\mathrm{VP}$ & $3.86 \pm 0.81^{\mathrm{B}}$ & $3.30 \pm 1.17^{\mathrm{ab} ; \mathrm{A}}$ & $3.25 \pm 1.09^{\mathrm{ab} ; \mathrm{A}}$ & $2.98 \pm 1.04^{\mathrm{ab} ; \mathrm{A}}$ & $2.89 \pm 1.03^{\mathrm{a} ; \mathrm{A}}$ & $2.98 \pm 0.93^{\mathrm{a} ; \mathrm{A}}$ \\
\hline & MAP & $3.86 \pm 0.81^{\mathrm{C}}$ & $3.47 \pm 1.17^{\mathrm{b} ; \mathrm{B}, \mathrm{C}}$ & $3.42 \pm 1.01^{\mathrm{b} ; \mathrm{B}, \mathrm{C}}$ & $3.13 \pm 1.10^{\mathrm{b} ; \mathrm{A}, \mathrm{B}}$ & $3.11 \pm 1.07^{\mathrm{a} ; \mathrm{A}, \mathrm{B}}$ & $2.92 \pm 1.09^{\mathrm{a} ; \mathrm{A}}$ \\
\hline \multirow[t]{3}{*}{ Typical odor } & WP & $4.66 \pm 0.59^{\mathrm{D}}$ & $3.47 \pm 1.07^{\mathrm{a} ; \mathrm{c}}$ & $3.40 \pm 1.05^{\mathrm{a} ; \mathrm{c}}$ & $2.13 \pm 0.91^{\mathrm{a} ; \mathrm{B}}$ & $2.26 \pm 1.04^{\mathrm{a} ; \mathrm{B}}$ & $1.31 \pm 0.62^{\mathrm{a} ; \mathrm{A}}$ \\
\hline & $\mathrm{VP}$ & $4.66 \pm 0.59^{\mathrm{D}}$ & $4.11 \pm 0.91^{\mathrm{b} ; \mathrm{C}}$ & $3.81 \pm 0.95^{\mathrm{b} ; \mathrm{B}, \mathrm{C}}$ & $3.79 \pm 0.80^{\mathrm{b} ; \mathrm{B}, \mathrm{C}}$ & $3.32 \pm 0.94^{\mathrm{b} ; \mathrm{A}}$ & $3.59 \pm 0.92^{\mathrm{b} ; \mathrm{A}, \mathrm{B}}$ \\
\hline & MAP & $4.66 \pm 0.59^{\mathrm{B}}$ & $4.02 \pm 0.89^{\mathrm{b} ; \mathrm{A}}$ & $4.08 \pm 0.84^{\mathrm{b} ; \mathrm{A}}$ & $3.77 \pm 0.83^{\mathrm{b} ; \mathrm{A}}$ & $4.17 \pm 0.73^{\mathrm{c} ; \mathrm{A}}$ & $3.82 \pm 0.95^{\mathrm{b} ; \mathrm{A}}$ \\
\hline \multirow[t]{3}{*}{ Off-odors } & WP & $1.00 \pm 0.00^{\mathrm{A}}$ & $1.38 \pm 0.60^{\mathrm{b} ; \mathrm{A}, \mathrm{B}}$ & $1.60 \pm 0.83^{\mathrm{b} ; \mathrm{B}}$ & $2.40 \pm 1,28^{\mathrm{b} ; \mathrm{C}}$ & $2.47 \pm 1.45^{\mathrm{b} ; \mathrm{c}}$ & $3.49 \pm 1.30^{\mathrm{b} ; \mathrm{D}}$ \\
\hline & VP & $1.00 \pm 0.00^{\mathrm{A}}$ & $1.21 \pm 0.50^{\mathrm{ab} ; \mathrm{A}, \mathrm{B}}$ & $1.23 \pm 0.58^{\mathrm{a} ; \mathrm{A}, \mathrm{B}}$ & $1.19 \pm 0.39^{\mathrm{a} ; \mathrm{A}}$ & $1.58 \pm 0.84^{\mathrm{a} ; \mathrm{c}}$ & $1.49 \pm 0.88^{\mathrm{a} ; \mathrm{B}, \mathrm{C}}$ \\
\hline & MAP & $1.00 \pm 0.00^{\mathrm{A}}$ & $1.09 \pm 0.35^{\mathrm{a} ; \mathrm{A}, \mathrm{B}}$ & $1.13 \pm 0.40^{\mathrm{a} ; \mathrm{A}, \mathrm{B}, \mathrm{C}}$ & $1.25 \pm 0.43^{\mathrm{a} ; \mathrm{B}, \mathrm{C}}$ & $1.25 \pm 0.68^{\mathrm{a} ; \mathrm{B}, \mathrm{C}}$ & $1.35 \pm 0.66^{\mathrm{a} ; \mathrm{c}}$ \\
\hline \multirow[t]{3}{*}{ Rancid } & WP & $1.00 \pm 0.00^{\mathrm{A}}$ & $1.32 \pm 0.61^{\mathrm{b} ; \mathrm{A}, \mathrm{B}}$ & $1.54 \pm 0.73^{\mathrm{b} ; \mathrm{B}}$ & $2.50 \pm 1.36^{\mathrm{b} ; \mathrm{c}}$ & $2.64 \pm 1.44^{\mathrm{b} ; \mathrm{c}}$ & $3.75 \pm 1.18^{\mathrm{b} ; \mathrm{D}}$ \\
\hline & $\mathrm{VP}$ & $1.00 \pm 0.00^{\mathrm{A}}$ & $1.04 \pm 0.19^{\mathrm{a} ; \mathrm{A}}$ & $1.10 \pm 0.36^{\mathrm{a} ; \mathrm{A}, \mathrm{B}}$ & $1.10 \pm 0.31^{\mathrm{a} ; \mathrm{A}, \mathrm{B}}$ & $1.26 \pm 0.56^{\mathrm{a} ; \mathrm{B}}$ & $1.24 \pm 0.62^{\mathrm{a} ; \mathrm{B}}$ \\
\hline & MAP & $1.00 \pm 0.00^{\mathrm{A}}$ & $1.02 \pm 0.14^{\mathrm{a} ; \mathrm{A}}$ & $1.04 \pm 0.28^{\mathrm{a} ; \mathrm{A}}$ & $1.02 \pm 0.14^{\mathrm{a} ; \mathrm{A}}$ & $1.15 \pm 0.50^{\mathrm{a} ; \mathrm{A}, \mathrm{B}}$ & $1.25 \pm 0.63^{\mathrm{a} ; \mathrm{B}}$ \\
\hline \multirow[t]{3}{*}{ Putrid } & WP & $1.00 \pm 0.00^{\mathrm{A}}$ & $1.04 \pm 0.19^{\mathrm{a} ; \mathrm{A}}$ & $1.00 \pm 0.00^{\mathrm{a} ; \mathrm{A}}$ & $1.17 \pm 0.52^{\mathrm{a} ; \mathrm{A}, \mathrm{B}}$ & $1.17 \pm 0.64^{\mathrm{a} ; \mathrm{A}, \mathrm{B}}$ & $1.25 \pm 0.74^{\mathrm{b} ; \mathrm{B}}$ \\
\hline & VP & $1.00 \pm 0.00^{\mathrm{A}}$ & $1.00 \pm 0.00^{\mathrm{a} ; \mathrm{A}}$ & $1.10 \pm 0.41^{\mathrm{a} ; \mathrm{A}, \mathrm{B}}$ & $1.08 \pm 0.35^{\mathrm{a} ; \mathrm{A}, \mathrm{B}}$ & $1.11 \pm 0.38^{\mathrm{a} ; \mathrm{A}, \mathrm{B}}$ & $1.20 \pm 0.75^{\mathrm{ab} ; \mathrm{B}}$ \\
\hline & MAP & $1.00 \pm 0.00^{\mathrm{A}}$ & $1.02 \pm 0.14^{\mathrm{a} ; \mathrm{A}}$ & $1.02 \pm 0.14^{\mathrm{a} ; \mathrm{A}}$ & $1.06 \pm 0.24^{\mathrm{a} ; \mathrm{A}}$ & $1.11 \pm 0.47^{\mathrm{a} ; \mathrm{A}}$ & $1.14 \pm 0.57^{\mathrm{a}, \mathrm{A}}$ \\
\hline \multirow[t]{3}{*}{ Sour/fermented } & WP & $1.00 \pm 0.00^{\mathrm{A}}$ & $1.11 \pm 0.32^{\mathrm{a} ; \mathrm{A}, \mathrm{B}}$ & $1.13 \pm 0.40^{\mathrm{a} ; \mathrm{A}, \mathrm{B}}$ & $1.46 \pm 0.87^{\mathrm{b} ; \mathrm{B}}$ & $1.47 \pm 0.93^{\mathrm{b} ; \mathrm{B}}$ & $1.98 \pm 1.21^{\mathrm{b} ; \mathrm{C}}$ \\
\hline & VP & $1.00 \pm 0.00^{\mathrm{A}}$ & $1.02 \pm 0.14^{\mathrm{a} ; \mathrm{A}}$ & $1.10 \pm 0.36^{\mathrm{a} ; \mathrm{A}, \mathrm{B}}$ & $1.21 \pm 0.50^{\mathrm{a} ; \mathrm{A}, \mathrm{B}}$ & $1.38 \pm 0.71^{\mathrm{ab} ; \mathrm{B}}$ & $1.35 \pm 0.66^{\mathrm{a} ; \mathrm{B}}$ \\
\hline & MAP & $1.00 \pm 0.00^{\mathrm{A}}$ & $1.02 \pm 0.14^{\mathrm{a} ; \mathrm{A}}$ & $1.10 \pm 0.36^{\mathrm{a} ; \mathrm{A}, \mathrm{B}}$ & $1.08 \pm 0.28^{\mathrm{a} ; \mathrm{A}, \mathrm{B}}$ & $1.19 \pm 0.59^{\mathrm{a} ; \mathrm{A}, \mathrm{B}}$ & $1.25 \pm 0.69^{\mathrm{a} ; \mathrm{B}}$ \\
\hline \multirow[t]{3}{*}{ Spoiled wine/vinegary } & WP & $1.02 \pm 0.14^{\mathrm{A}}$ & $1.09 \pm 0.30^{\mathrm{a} ; \mathrm{A}, \mathrm{B}}$ & $1.13 \pm 0.40^{\mathrm{a} ; \mathrm{A}, \mathrm{B}}$ & $1.23 \pm 0.51^{\mathrm{b} ; \mathrm{A}, \mathrm{B}}$ & $1.34 \pm 0.73^{\mathrm{b} ; \mathrm{B}, \mathrm{C}}$ & $1.59 \pm 0.92^{\mathrm{b} ; \mathrm{c}}$ \\
\hline & VP & $1.02 \pm 0.14^{\mathrm{A}}$ & $1.08 \pm 0.33^{\mathrm{a} ; \mathrm{A}, \mathrm{B}}$ & $1.08 \pm 0.27^{\mathrm{a} ; \mathrm{A}, \mathrm{B}}$ & $1.08 \pm 0.28^{\mathrm{a}, \mathrm{b} ; \mathrm{A}, \mathrm{B}}$ & $1.25 \pm 0.52^{\mathrm{a}, \mathrm{b} ; \mathrm{B}}$ & $1.22 \pm 0.61^{\mathrm{a} ; \mathrm{B}}$ \\
\hline & MAP & $1.02 \pm 0.14^{\mathrm{A}}$ & $1.02 \pm 0.14^{\mathrm{a} ; \mathrm{A}}$ & $1.08 \pm 0.33^{\mathrm{a} ; \mathrm{A}}$ & $1.06 \pm 0.32^{\mathrm{a} ; \mathrm{A}}$ & $1.13 \pm 0.48^{\mathrm{a} ; \mathrm{A}}$ & $1.16 \pm 0.50^{\mathrm{a} ; \mathrm{A}}$ \\
\hline \multirow[t]{3}{*}{ Moldy/mildew } & WP & $1.00 \pm 0.00^{\mathrm{A}}$ & $1.04 \pm 0.19^{\mathrm{a} ; \mathrm{A}}$ & $1.04 \pm 0.19^{\mathrm{a} ; \mathrm{A}}$ & $1.27 \pm 0.57^{\mathrm{b} ; \mathrm{A}, \mathrm{B}}$ & $1.38 \pm 0.79^{\mathrm{b} ; \mathrm{B}, \mathrm{C}}$ & $1.67 \pm 0.97^{\mathrm{b} ; \mathrm{c}}$ \\
\hline & VP & $1.00 \pm 0.00^{\mathrm{A}}$ & $1.02 \pm 0.14^{\mathrm{a} ; \mathrm{A}}$ & $1.06 \pm 0.31^{\mathrm{a} ; \mathrm{A}}$ & $1.04 \pm 0.20^{\mathrm{a} ; \mathrm{A}}$ & $1.11 \pm 0.42^{\mathrm{a} ; \mathrm{A}}$ & $1.14 \pm 0.53^{\mathrm{a} ; \mathrm{A}}$ \\
\hline & MAP & $1.00 \pm 0.00^{\mathrm{A}}$ & $1.02 \pm 0.14^{\mathrm{a} ; \mathrm{A}, \mathrm{B}}$ & $1.04 \pm 0.19^{\mathrm{a} ; \mathrm{A}, \mathrm{B}}$ & $1.02 \pm 0,14^{\mathrm{a} ; \mathrm{A}, \mathrm{B}}$ & $1.11 \pm 0.42^{\mathrm{a} ; \mathrm{A}, \mathrm{B}}$ & $1.16 \pm 0.54^{\mathrm{a} ; \mathrm{B}}$ \\
\hline \multirow[t]{3}{*}{ Typical flavor } & WP & $4.62 \pm 0.57^{\mathrm{D}}$ & $3.29 \pm 1.11^{\mathrm{a} ; \mathrm{c}}$ & $2.98 \pm 0.96^{\mathrm{a} ; \mathrm{c}}$ & $2.04 \pm 1.07^{\mathrm{a} ; \mathrm{B}}$ & $2.12 \pm 0.90^{\mathrm{a} ; \mathrm{B}}$ & $1.20 \pm 0.46^{\mathrm{a} ; \mathrm{A}}$ \\
\hline & VP & $4.62 \pm 0.57^{\mathrm{D}}$ & $3.96 \pm 0.90^{\mathrm{b} ; \mathrm{c}}$ & $3.85 \pm 0.98^{\mathrm{b} ; \mathrm{B}, \mathrm{C}}$ & $3.67 \pm 0.86^{\mathrm{b} ; \mathrm{A}, \mathrm{B}, \mathrm{C}}$ & $3.32 \pm 0.83^{\mathrm{b} ; \mathrm{A}, \mathrm{B}}$ & $3.42 \pm 0.93^{\mathrm{b} ; \mathrm{A}, \mathrm{B}}$ \\
\hline & MAP & $4.62 \pm 0.57^{\mathrm{B}}$ & $3.96 \pm 0.92^{\mathrm{b} ; \mathrm{A}}$ & $4.12 \pm 0.81^{\mathrm{b} ; \mathrm{A}}$ & $3.71 \pm 0.82^{\mathrm{b} ; \mathrm{A}}$ & $4.02 \pm 0.84^{\mathrm{c} ; \mathrm{A}}$ & $3.70 \pm 0.97^{\mathrm{b} ; \mathrm{A}}$ \\
\hline \multirow[t]{3}{*}{ Acid } & WP & $1.12 \pm 0.39^{\mathrm{A}}$ & $1.23 \pm 0.51^{\mathrm{a} ; \mathrm{A}, \mathrm{B}}$ & $1.27 \pm 0.63^{\mathrm{a} ; \mathrm{A}, \mathrm{B}}$ & $1.52 \pm 0.84^{\mathrm{b} ; \mathrm{B}, \mathrm{C}}$ & $1.67 \pm 1.14^{\mathrm{b} ; C, D}$ & $2.00 \pm 1.26^{\mathrm{b} ; \mathrm{D}}$ \\
\hline & VP & $1.12 \pm 0.39^{A}$ & $1.13 \pm 0.39^{\mathrm{a} ; \mathrm{A}}$ & $1.13 \pm 0.40^{\mathrm{a} ; \mathrm{A}}$ & $1.23 \pm 0.63^{\mathrm{a} ; \mathrm{A}}$ & $1.25 \pm 0.65^{\mathrm{a} ; \mathrm{A}}$ & $1.28 \pm 0.57^{\mathrm{a} ; \mathrm{A}}$ \\
\hline & MAP & $1.12 \pm 0.39^{\mathrm{A}}$ & $1.19 \pm 0.48^{\mathrm{a} ; \mathrm{A}}$ & $1.13 \pm 0.40^{\mathrm{a} ; \mathrm{A}}$ & $1.13 \pm 0.39^{\mathrm{a} ; \mathrm{A}}$ & $1.21 \pm 0.60^{\mathrm{a} ; \mathrm{A}}$ & $1.26 \pm 0.53^{\mathrm{a} ; \mathrm{A}}$ \\
\hline \multirow[t]{3}{*}{ Bitter } & WP & $1.06 \pm 0.24^{\mathrm{A}}$ & $1.12 \pm 0.43^{\mathrm{a} ; \mathrm{A}, \mathrm{B}}$ & $1.25 \pm 0.56^{\mathrm{a} ; \mathrm{A}, \mathrm{B}, \mathrm{C}}$ & $1.52 \pm 0.84^{\mathrm{b} ; \mathrm{B}, \mathrm{C}}$ & $1.63 \pm 1.09^{\mathrm{b} ; \mathrm{C}, \mathrm{D}}$ & $2.03 \pm 1.40^{\mathrm{b} ; \mathrm{D}}$ \\
\hline & VP & $1.06 \pm 0.24^{\mathrm{A}}$ & $1.11 \pm 0.38^{\mathrm{a} ; \mathrm{A}}$ & $1.10 \pm 0.36^{\mathrm{a} ; \mathrm{A}}$ & $1.15 \pm 0.46^{\mathrm{a} ; \mathrm{A}}$ & $1.19 \pm 0.56^{\mathrm{a} ; \mathrm{A}}$ & $1.24 \pm 0.52^{\mathrm{a} ; \mathrm{A}}$ \\
\hline & MAP & $1.06 \pm 0.24^{\mathrm{A}}$ & $1.09 \pm 0.35^{\mathrm{a} ; \mathrm{A}, \mathrm{B}}$ & $1.12 \pm 0.38^{\mathrm{a} ; \mathrm{A}, \mathrm{B}}$ & $1.08 \pm 0.35^{\mathrm{a} ; \mathrm{A}, \mathrm{B}}$ & $1.13 \pm 0.44^{\mathrm{a} ; \mathrm{A}, \mathrm{B}}$ & $1.26 \pm 0.63^{\mathrm{a} ; \mathrm{B}}$ \\
\hline \multirow[t]{3}{*}{ Global freshness } & WP & $4.68 \pm 0.55^{\mathrm{D}}$ & $3.11 \pm 1.15^{\mathrm{a} ; \mathrm{c}}$ & $2.79 \pm 0.99^{\mathrm{a} ; \mathrm{c}}$ & $1.79 \pm 0.82^{\mathrm{a} ; \mathrm{B}}$ & $1.72 \pm 0.69^{\mathrm{a} ; \mathrm{B}}$ & $1.16 \pm 0.42^{\mathrm{a} ; \mathrm{A}}$ \\
\hline & VP & $4.68 \pm 0.55^{\mathrm{C}}$ & $3.94 \pm 1.01^{\mathrm{b} ; \mathrm{B}}$ & $3.94 \pm 0.91^{\mathrm{b} ; \mathrm{B}}$ & $3.48 \pm 1.01^{\mathrm{b} ; \mathrm{A}, \mathrm{B}}$ & $3.21 \pm 0.95^{\mathrm{b} ; \mathrm{A}}$ & $3.37 \pm 0.96^{\mathrm{b} ; \mathrm{A}}$ \\
\hline & MAP & $4.68 \pm 0.55^{C}$ & $4.02 \pm 0.95^{\mathrm{b} ; \mathrm{A}, \mathrm{B}}$ & $4.11 \pm 0.80^{\mathrm{b} ; \mathrm{B}}$ & $3.67 \pm 0.86^{\mathrm{b} ; \mathrm{A}}$ & $3.92 \pm 0.78^{\mathrm{c} ; \mathrm{A}, \mathrm{B}}$ & $3.73 \pm 1.04^{\mathrm{b} ; \mathrm{A}, \mathrm{B}}$ \\
\hline \multirow{3}{*}{ Global freshness of packed ${ }^{3}$} & WP & $4.82 \pm 0.48^{2}$ & $3.57 \pm 1.01^{\mathrm{a} ; \mathrm{D}}$ & $3.04 \pm 1.07^{\mathrm{a} ; \mathrm{c}}$ & $2.17 \pm 0.93^{\mathrm{a} ; \mathrm{B}}$ & $1.83 \pm 0.89^{\mathrm{a} ; \mathrm{B}}$ & $1.33 \pm 0.55^{\mathrm{a} ; \mathrm{A}}$ \\
\hline & VP & $4.82 \pm 0.48$ & $4.11 \pm 0.99^{b ; c}$ & $4.06 \pm 0.95^{\mathrm{b} ; \mathrm{c}}$ & $3.21 \pm 1.13^{\mathrm{b} ; \mathrm{B}}$ & $2.87 \pm 0.90^{\mathrm{b} ; \mathrm{A}, \mathrm{B}}$ & $2.57 \pm 0.81^{\mathrm{b} ; \mathrm{A}}$ \\
\hline & MAP & $4.82 \pm 0.48$ & $4.15 \pm 0.84^{\mathrm{b} ; \mathrm{A}}$ & $4.25 \pm 0.90^{\mathrm{b} ; \mathrm{A}}$ & $4.06 \pm 0.70^{\mathrm{c} ; \mathrm{A}}$ & $3.89 \pm 0.82^{\mathrm{c} ; \mathrm{A}}$ & $3.92 \pm 0.93^{\mathrm{c} ; \mathrm{A}}$ \\
\hline
\end{tabular}

a-c -means with different lowercase letters in the same column/parameter are significantly different $(p<0.05)$.

A-D -means with different uppercase letters in the same row are significantly different $(p<0.05)$.

1 The first sampling time (day 0) was made before packaging. Mean values were repeated for the three packages only for comparison between storage times.

2 For global freshness of packaged product, in the day 0 of the study assessors evaluated only the unpackaged product.

3 Global freshness of the entire packed product (external appearance).

faster deterioration detected by the sensory panel, WP samples did not have a clearly worst microbiological profile, as it might be expected. The reduction of $a_{\mathrm{w}}$ due to the drying effect produced a delay in the growth of the microbiota. Despite the small absolute reduction in the $a_{\mathrm{w}}$ during the experiment ( 0.02 units of $a_{\mathrm{w}}$ ), it occurred at an interval that began to have inhibitory effect on microbiota, particularly on Gram-negative bacteria (Adams \& Moss, 2008).

The presence of spore formers like $B$. cereus was probably associated to the contamination of the raw materials and/or to the insufficient heat treatment to inactivate the spores. Nevertheless it does not compromise the safety of MA, once the infective dose for diarrheal or emetic syndrome is clearly higher (Arnesen, Fagerlund, \& Granum, 2008) than the counts observed in MA.

The post cooking contamination was probably the main responsible for the MTVC, PTVC and LAB counts observed immediately after processing. Even for thermoduric non-spore former Gram-positive bacteria, the heat treatment associated to the cooking of MA was very intense to allow their survival. Once MA was produced at one industry that produces dry-cured meat products, it is acceptable to consider that the contamination of MA was made from the house flora of the industry, composed mainly by Gram positive bacteria, particularly LAB (Mäkelä \& Korkeala, 1987). The total viable counts might be also composed by spore formers that survived to the heat treatment (Korkeala, Lindroth, Suihko, Kuhmonen, \& Penttilä, 1985). The behavior of total viable counts (MTVC and PTVC) was similar along the experiment, without a clear pattern of differences between MA packaged with different technologies. These results might be justified by the qualitative composition of these total counts. Once the different spoilage microorganisms have particular behaviors in each packaging technology, and it is expected to have a substitution effect when one group is inhibited, the 
Table 2

Selected Pearson correlations between microbial counts and sensorial evaluation of global freshness $(r, p)$.

\begin{tabular}{llll}
\hline Microbial group & WP & VP & MAP \\
\hline MTVC & $-0.86,<0.001$ & $-0.72,0.004$ & $-0.72,0.004$ \\
PTVC & $-0.83,<0.001$ & $-0,73,0.003$ & $-0,77,0.001$ \\
LAB & $-0.74,0.002$ & $-0.85,<0.001$ & $-0.88,<0.001$ \\
Enterobacteriaceae & $-0.49, \mathrm{~ns}$ & $-0.76,0.002$ & $-0.33, \mathrm{~ns}$ \\
Pseudomonas spp. & $-0.90,<0.001$ & $-0.74,<0.001$ & $-0.33, \mathrm{~ns}$ \\
\hline
\end{tabular}

ns, not significant $(p>0.05)$.

similar MTVC and PTVC were composed by the specific dominant spoilage group in each package. LAB were the dominant spoilage microbiota in VP samples as they usually are in VP meat products (Korkeala \& Björkroth, 1997). The microaerophilic needs justifies the ability to grow well in VP, once they can use trace amounts of oxygen dissolved in the VP product (Buchanan, 1986; Korkeala \& Björkroth, 1997). MAP and WP samples had similar LAB counts. The reduction of growth in MAP MA can be attributed to the direct effect of carbon dioxide, once it has significant effect on the extension of the lag phase and generation time of certain LAB (Devlieghere, Debevere, \& Van Impe, 1998). That was confirmed by the results of Santos, Jaime, et al. (2005), who found an inhibitory effect of MAP $\left(80 \% \mathrm{CO}_{2} / 20 \% \mathrm{~N}_{2}\right)$ in the growth of LAB comparatively to VP. However, other authors (Cachaldora et al., 2013; Pexara et al., 2002; Samelis \& Georgiadou, 2000) reported that the use of MAP with different amounts of carbon dioxide in cooked meat products did not affect the growth rate of LAB when compared to the use of VP. That apparent controversy might be due to the LAB species present. According to the results obtained in Spanish blood sausages (Diez et al., 2008; Santos, Diez, González-Fernández, Jaime, \& Rovira, 2005; Santos, Jaime, et al., 2005) the associated spoilage LAB were heterofermentative mainly members of Leuconostoc and Weissella genus, that were reported to be more inhibited by high concentration of carbon dioxide. In MA stored WP, the low level of carbon dioxide, combined with the high $a_{\mathrm{w}}$ in the beginning of the storage and low temperature gave a competitive disadvantage to LAB against other psychrotrophic aerobes, namely Pseudomonas spp. (Huis in't Veld, 1996).

The behavior of Enterobacteriaceae was similar to that of Spanish Morcilla using the same MAP of the present work (Santos, Jaime, et al., 2005). In VP and WP samples, Enterobacteriaceae were detected from the day 8 of storage and grew until the day 22 . After that, the reduction observed in the Enterobacteriaceae in WP samples was probably due to the reduction of $a_{\mathrm{w}}$ that was more pronounced in this interval. The continuous growth of Enterobacteriaceae until the end of storage period in VP samples was associated to their facultative anaerobic character. The inhibitory effect of carbon dioxide, which is particularly efficient in Gram-negative bacteria (Mullan \& McDowell, 2003), justifies the low counts observed in MAP. As expected, the behavior of Pseudomonas spp. was highly conditioned by the packaging technology. In WP these aerobic microorganisms grow to higher levels, while the $a_{\mathrm{w}}$ was compatible with their needs. VP retarded considerably the growth of Pseudomonas spp. The best inhibitory effect was obtained when MA was packaged in MAP, once this group of spoilage microorganism was present, during all the experiment, in very low counts. In addition to oxygen depletion in the packaging by substitution by nitrogen and carbon dioxide, the direct inhibitory effect of $\mathrm{CO}_{2}$ was the responsible for the strong inhibition of these Gram-negative aerobic bacteria.

The absence of package as it is usually done by the producers of MA revealed to be the worst choice for the maintenance of the sensory characteristics. These MA supported well the growth of all the spoilage microorganisms studied, resulting in the development of off-odors and sooner than when package is used. Additionally, the absence of package could have contributed to the loss of the characteristic aromas by volatilization and the oxidation of lipids, as inferred by the higher scores for rancid odor. The oxidation of lipids might also have been favored by the high count of Pseudomonas spp. in these samples. These bacteria have an important lipolytic activity (Huis in't Veld, 1996), resulting at one increase of free fatty acids which favors the oxidation phenomena once free fatty acids are more easily oxidized than when esterified in triglycerides (Hamilton, 1994). The introduction of VP represents an improvement in the shelf life. The product maintained good sensorial characteristics during storage, however, mainly due to the growth of $\mathrm{LAB}$ and Enterobacteriaceae it losses the freshness. The use of MAP revealed to be the best solution to increase shelf life of MA, once almost all the sensory traits were maintained during the 44 days of storage. Though these samples presented high counts of $\mathrm{LAB}$, the principal spoilage microbial group in these MA, the impact of these microorganisms in sensory characteristics was modest, once they have a weak lipolytic and catabolic activity over nitrogen fraction, when compared to Enterobacteriaceae and Pseudomonas spp. (Huis in't Veld, 1996).

Depending on the initial quality of the product, storage temperature and package construction and design, shelf life of cooked meat products can be extend by two- to four-fold with MAP (Hotchkiss \& Langston, 1995). $\mathrm{CO}_{2} / \mathrm{N}_{2}$ atmospheres are referred as particularly adequate for the preservation of cooked meat products, mainly because of the strong inhibition of the growth of the great majority of microorganisms and of the oxidative phenomena (Hintlian \& Hotchkiss, 1987; Matos et al., 2005; Summo, Caponio, Tricarico, Pasqualone, \& Gomes, 2010).

\section{Conclusions}

The present traditional storage and distribution procedure of MA from Monchique region, without packaging, compromises the shelf life of this difficult to preserve ready to eat blood sausage, which was evidenced by sensory and microbiological results, and contributes to considerable economic losses for the producers by compromising the commercialization and the conquest of other markets. Accordingly to the results of the behavior of the microbial groups during the storage period, Enterobacteriaceae is associated particularly to the loss of freshness in VP, and Pseudomonas spp. in WP samples. MAP using $80 \% \mathrm{CO}_{2}$ and $20 \%$ $\mathrm{N}_{2}$, by its inhibition effect on the growth of LAB, Enterobacteriaceae and Pseudomonas spp. and on rancidity revealed to be the most efficient on extending the shelf life of Morcela de Arroz.

\section{Conflict of interest}

The authors have no conflict of interest to declare.

\section{Acknowledgments}

This work received financial support from FCT-Portuguese Foundation for Science and Technology through PhD grant SFRH/BD/63341/ 2009.

\section{References}

Adams, M.R., \& Moss, M.O. (2008). Food microbiology (3rd ed.). Guildford: The Royal Society of Chemistry.

Arnesen, L.P.S., Fagerlund, A., \& Granum, P.E. (2008). From soil to gut: Bacillus cereus and its food poisoning toxins. Review article. FEMS Microbiology Reviews, 32, 579-606.

Borch, E., Kant-Muermans, M. L., \& Blixt, Y. (1996). Bacterial spoilage of meat and cured meat products. International Journal of Food Microbiology, 33, 103-120.

Braghieri, A., Piazzolla, N., Carlucci, A., Monteleone, E., Girolami, A., \& Napolitano, F. (2012). Development and validation of a quantitative frame of reference for meat sensory evaluation. Food Quality and Preference, 25, 63-68.

Buchanan, R.L. (1986). Processed meats as a microbial environment. Food Technology, 40, 134-138.

Cachaldora, A., García, G., Lorenzo, J.M., \& García-Fontán, M.C. (2013). Effect of modified atmosphere and vacuum packaging on some quality characteristics and the shelf life of morcilla, a typical cooked blood sausage. Meat Science, 93, 220-225.

Devlieghere, F., Debevere, J., \& Van Impe, J. (1998). Concentration of carbon dioxide in the water-phase as a parameter to model the effect of a modified atmosphere on microorganisms. International Journal of Food Microbiology, 43, 105-113.

Diez, A.M., Urso, R., Rantsiou, K., Jaime, I., Rovira, J., \& Cocolin, L. (2008). Spoilage of blood sausages "morcilla de Burgos" treated with high hydrostatic pressure. Internationa Journal of Food Microbiology, 123, 246-253. 
EN 12824 (1997). Microbiology of food and animal feeding stuffs. Horizontal method for the detection of Salmonella spp. Part 1: Detection method. Brussels, Belgium: European Committee for Standardization.

Hamilton, R.J. (1994). The chemistry of rancidity in foods. In J.C. Allen, \& R.J. Hamilton (Eds.), Rancidity in foods (pp. 1-21). London: Blackie Academic and Professional.

Hintlian, C.B., \& Hotchkiss, J.H. (1987). Comparative growth of spoilage and pathogenic organisms on modified atmosphere packaged cooked beef. Journal of Food Protection, 50, 218-223.

Hotchkiss, J.H., \& Langston, S.W. (1995). MAP of cooked meat and poultry products. In J.M. Farber, \& K.L. Dodds (Eds.), Principles of modified atmosphere and sous vide product packaging (pp. 137-152). Lancaster: Technomic Publishing Co.

Huis in't Veld, J.H.J. (1996). Microbial and biochemical spoilage of foods: An overview. International Journal of Food Microbiology, 33, 1-18.

IBM Corp. (2010). IBM SPSS statistics for Windows, version 19.0. New York: IBM Corp.

ISO 11035 (1994). Sensory analysis. Identification and selection of descriptors for establishing a sensory profile by a multidimensional approach. Genève, Switzerland: International Organization for Standardization.

ISO 11290-1 (1996). Microbiology of food and animal feeding stuffs. Horizontal method for the detection and enumeration of Listeria monocytogenes. Part 1: Detection method. Genève, Switzerland: International Organization for Standardization.

ISO 7932 (2004). Microbiology of food and animal feeding stuffs. Horizontal method for the enumeration of presumptive Bacillus cereus. Colony-count technique at $30{ }^{\circ} \mathrm{C}$. Genève, Switzerland: International Organization for Standardization.

ISO 7937 (2004). Microbiology of food and animal feeding stuffs. Horizontal method for the enumeration of Clostridium perfringens. Colony-count technique. Genève, Switzerland: International Organization for Standardization.

ISO 8586-1 (1993). Sensory analyses. General guidance for the selection, training and monitoring of assessors. Part 1: Selected assessors. Genève, Switzerland: International Organization for Standardization.

Jarmoluk, A., \& Pietrasik, Z. (2003). Response surface methodology study on the effects of blood plasma, microbial transglutaminase and kappa-carrageenan on pork batter gel properties. Journal of Food Engineering, 60, 327-334.

Korkeala, H.J., \& Björkroth, K.J. (1997). Microbiological spoilage and contamination of vacuum-packed cooked sausages. Journal of Food Protection, 60, 724-731.

Korkeala, H., Lindroth, S., Suihko, M., Kuhmonen, A., \& Penttilä, P.L. (1985). Microbiological and sensory quality changes in blood pancakes and cooked ring sausage during storage. International Journal of Food Microbiology, 2, 279-292.

Le Maguer, M. (1987). Mechanics and influence of water binding on water activity. In L.B. Rockland, \& L.R. Beauchat (Eds.), Water activity: Theory and application to food (pp. 1-25). New York: Marcel Dekker.

Mäkelä, P., \& Korkeala, H. (1987). Lactobacillus contamination of cooked ring sausages at sausage processing plants. International Journal of Food Microbiology, 5, 323-330.
Matos, T.J.S., Barreto, A.S.F.H., \& Bernardo, F.M.A. (2005). Effect of shelf life period in modified atmosphere package and of processing technology on microflora of Portuguese smoked dry sausages. Rev. Port. Zootec., 2, 15-35.

McMillin, K.W. (2008). Where is MAP going? A review and future potential of modified atmosphere packaging for meat. Meat Science, 80, 43-65.

Mullan, M., \& McDowell, D. (2003). Modified atmosphere packaging. In R. Coles, D. McDowell, \& M.J. Kirwan (Eds.), Food packaging technology (pp. 303-338). Boca Raton: CRC Press.

Oteiza, J.M., Chinen, I., Miliwebsky, E., \& Rivas, M. (2006). Isolation and characterization of Shiga toxin-producing Escherichia coli from precooked sausages (morcillas). Food Microbiology, 23, 283-288.

Pereira, J.A., Ferreira-Dias, S., \& Matos, T.J.S. (2008). Application of unsteady-state heat transfer equations to Portuguese traditional meat products from Monchique region. Proceedings of the 54th International Congress of Meat Science and Technology, 10-15th August, Cape Town, South Africa (pp. 98).

Pexara, E.S., Metaxopoulos, J., \& Drosinos, E.H. (2002). Evaluation of shelf life of cured, cooked, sliced turkey fillets and cooked pork sausages-"piroski"-stored under vacuum and modified atmosphere at +4 and $+10{ }^{\circ} \mathrm{C}$. Meat Science, $62,33-43$.

Roseiro, L.C., Santos, C., Almeida, J., \& Vieira, J.A. (1998). Influence of packaging and storage temperature on cured pork blood sausages shelf life. Proceedings of the 44th International Congress of Meat Science and Technology, 30th August-4th September, Barcelona, Spain (pp. 430-431).

Samelis, J., \& Georgiadou, K.G. (2000). The microbial association of Greek taverna sausage stored at 4 and $10{ }^{\circ} \mathrm{C}$ in air, vacuum or $100 \%$ carbon dioxide, and its spoilage potential. Journal of Applied Microbiology, 88, 58-68.

Santos, E.M., Diez, A.M., González-Fernández, C., Jaime, I., \& Rovira, J. (2005). Microbiological and sensory changes in "Morcilla de Burgos" preserved in air, vacuum and modified atmosphere packaging. Meat Science, 71, 249-255.

Santos, E.M. González-Fernández, C. Jaime, I. \& Rovira, J. (2003). Physicochemical and sensory characterization of Morcilla de Burgos, a traditional Spanish blood sausage. Meat Science, 65, 893-898.

Santos, E.M., Jaime, I., Rovira, J., Lyhs, U., Korkeala, H., \& Björkroth, J. (2005). Characterization and identification of lactic acid bacteria in "morcilla de Burgos". International Journal of Food Microbiology, 97, 285-296.

Silva, F.V.M., \& Gibbs, P.A. (2010). Non-proteolytic Clostridium botulinum spores in lowacid cold distributed foods and design of pasteurization processes. Trends in Food Science E Technology, 21, 95-105.

Summo, C., Caponio, F., Tricarico, F., Pasqualone, A., \& Gomes, T. (2010). Evolution of the volatile compounds of ripened sausages as a function of both storage time and composition of packaging atmosphere. Meat Science, 86, 839-844. 